старший преподаватель кафедры финансов, финансового права, экономики и бухгалтерского учета, Институт экономики и права,

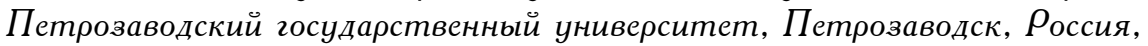
e-mail: l_shobey@mail.ru

СЕМЧЕНКО МАРИЯ ПЕТРОВНА студент Института экономики и права, Петрозаводский государственный университет, Петрозаводск, $\rho_{\text {оссия }}$ e-mail: semchenkomary@mail.ru

\title{
ЦИФРОВИЗАЦИЯ СТРАХОВОГО РЫНКА РОССИИ: СОСТОЯНИЕ, ПРОБАЕМЫ И ПЕРСПЕКТИВЫ
}

\begin{abstract}
Аннотауия. В данной статье рассматривается развитие электронного страхования в

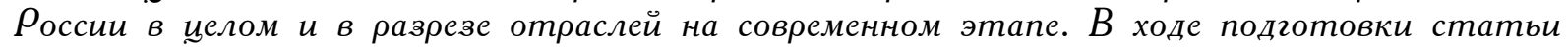
был использован метод статистического анализа экономических показателей страхового рынка, исследования сайтов страховых компаний. Изучены основные направления иифровизащии (интернетизащия, индивидуализащия и диджитализащия), подразумевающие внедрение информационных технологий не только в работу с клиентами, но и во внутренние прочессы деятельности страховщиков. В результате анализа прочесса иифровизации российского страхового рынка были сделаны выводы о росте применения цифровых технологий российскими страховыми компаниями. Несмотря на то что ииифровизация

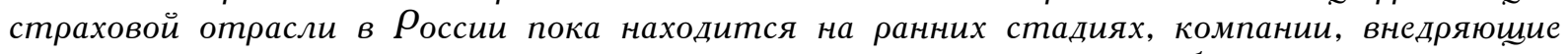
иифровые приложения и сервисы в свою деятельность, несомненно, будут иметь преимущества перед конкурентами, поскольку будут предлагать наиболее подходящий формат взаимодействия для удовлетворения постоянно меняющихся потребностей клиентов.
\end{abstract}

Ключевые слова: страхование, страховой рынок, цифровизация, цифровые технологии.

SHOBEY LARISA GENNADYEVNA

Senior Lecturer of the Department of Finance, Financial Law, Economics and Accounting, Institute of

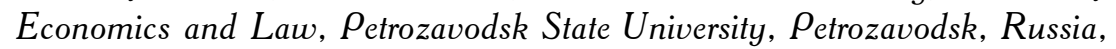
e-mail: l_shobey@mail.ru

SEMCHENKO MARIA PETROVNA

Student of the Institute of Economics and Law,

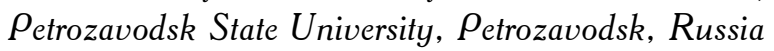
e-mail: semchenkomary@mail.ru

\section{DIGITALIZATION OF THE RUSSIAN INSURANCE MARKET: STATUS, PROBLEMS AND PROSPECTS}

\begin{abstract}
This article examines the development of electronic insurance in Russia as a whole and in the context of industries at the present stage. During the preparation of the article, the method of statistical analysis of economic indicators of the insurance market, research of insurance companies ' websites was used. The main directions of digitalization (internetization, individualization and digitalization), implying the introduction of information technologies not only in working with clients, but also in the internal processes of insurers ' activities, are studied. As a result of the analysis of the process of digitalization of the Russian insurance market, conclusions were drawn about the growth of the use of digital technologies by Russian insurance companies. Despite the fact that the digitalization of the insurance industry in Russia is still in its early stages, companies implementing digital applications and services in their activities will undoubtedly have advantages over competitors, since they will offer the most suitable format of interaction to meet the constantly changing needs of customers.
\end{abstract}

Keywords: insurance, insurance market, digitalization, digital technologies. 
Введение. До недавнего времени страхование считалось одной из самых консервативных сфер, неохотно внедряющих цифровые технологии в свою деятельность. Однако на фоне тенденции тотальной цифровизации экономики страховой рынок не смог остаться в стороне и начал трансформироваться. К тому же распространение коронавирусной инфекции Covid-19 лишь ускорило этот процесс.

Одним из ключевых направлений Стратегии развития страховой отрасли Российской Федерации на 2019-2021 гг., разработанной Всероссийским союзом страховщиков, является развитие электронного (цифрового) страхования. Цифровое страхование заключается во внедрении в страховую деятельность информационных технологий. По данным рейтингового агентства «Эксперт РА», в 2019 г. объем страховых премий по электронному страхованию без учета

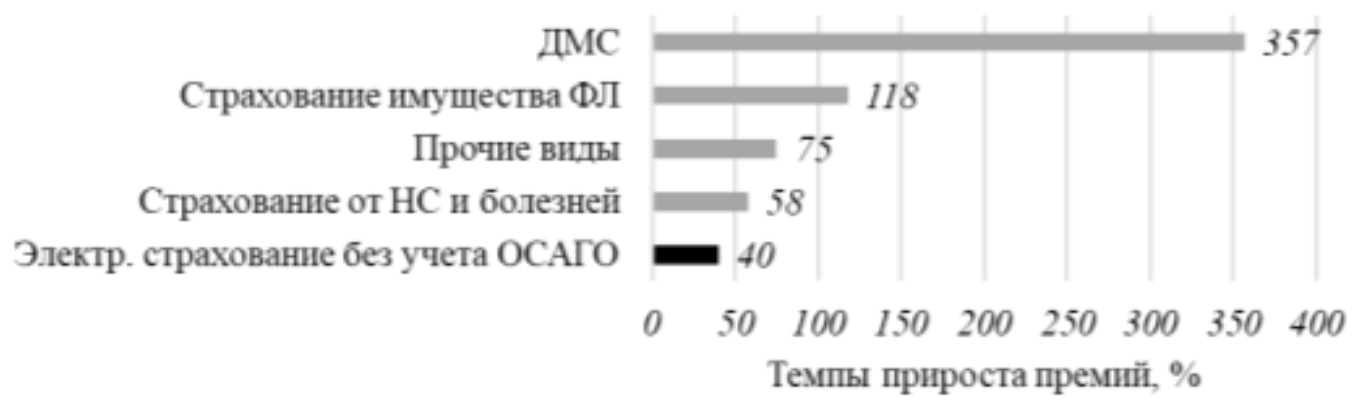

Pис. 1. Темпы прироста премий по электронному страхованию в разрезе отдельных видов в 2019 г. по сравнению с 2018 г., \%

Источник: составлено по данным рейтингового агентства «Эксперт РА» [1].

Структура электронного страхования по видам за 2017-2019 гг. (рис. 2) показала следующую динамику: значительное сокращение доли страхования автокаско с 44 до 24,3\%, увеличение доли страхования имущества физических лиц с 10,2 до 20,2\%. Также стоит отметить, что в 2019 г. превалирующее место в структуре премий заняли прочие виды страхования. Их доля составила 26,2\%, что на 11,7 п.п. больше показателя 2017 г. Существенную часть прочих ви-

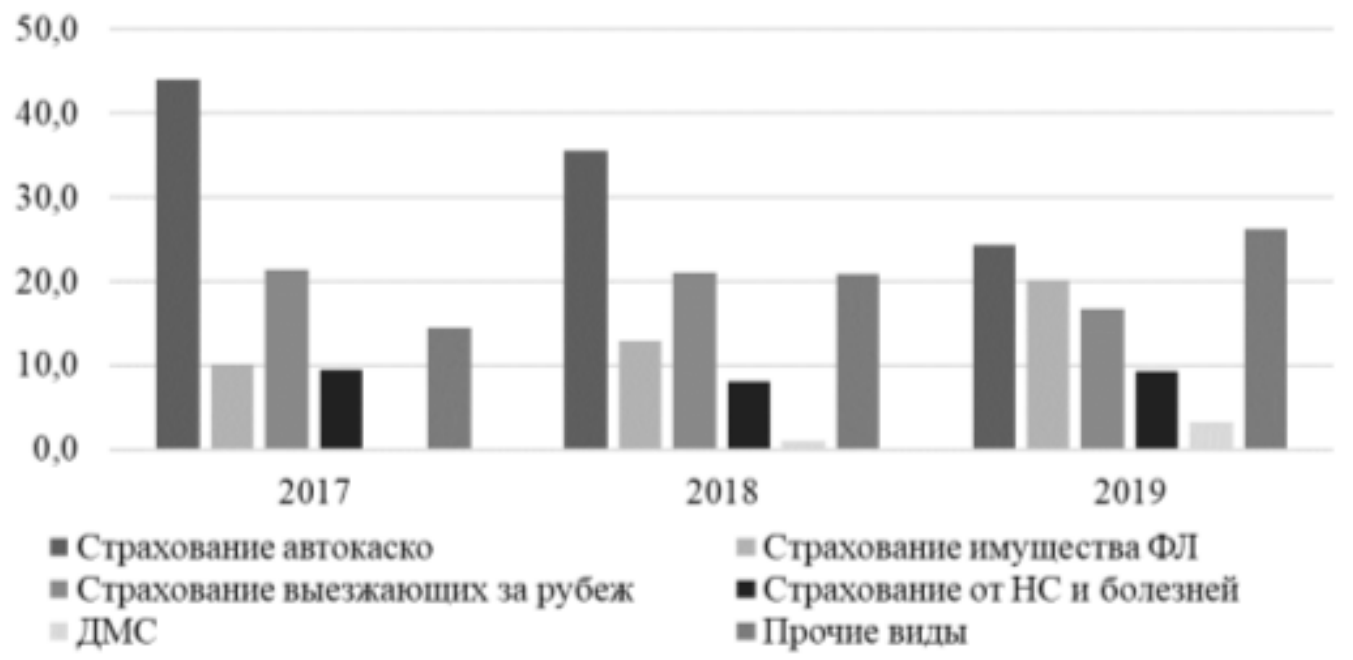

Pис. 2. Динамика структуры электронного страхования по видам без учета ОСАГО в 2017-2019 г2., \%

Источник: составлено по данным рейтингового агентства «Эксперт РА» [1].

Важно отметить, что в декабре 2020 г. появился индекс цифрового застрахованного (ИЦЗ), разработанный Всероссийским союзом страховщиков и АC\&M. Это первый аналитический показатель в России, оценивающий уровень цифровизации страховых продуктов и услуг для клиентов-физических лиц. Показатель рассчитывается на основе трех групп параметров: во- 
первых, данные страховых компаний, позволяющие оценить степень цифровизации их услуг, во-вторых, социологический опрос потребителей для оценки качества клиентского опыта в цифровых каналах продаж и, в-третьих, готовность населения к полному переходу в онлайн. По итогам первого полугодия 2020 г. значение ИЦЗ составило 43\%, что свидетельствует о высокой доступности цифровых страховых сервисов и доверии к ним населения. Это отражает переломный момент в проникновении цифровых технологий в страховые услуги. Страховые компании широко внедряют цифровые решения, однако пока еще существует большой потенциал для роста в этом направлении [2].

Основная часть. Направления цифровизации страхового рынка и их анализ.

2020 г. для российского страхового рынка стал «годом цифрового прорыва». Страховщики вынуждены были в кратчайшие сроки перевести отношения с клиентами, собственными сотрудниками и государственными органами в онлайн. Перед ними встала задача создания непрерывности во всех звеньях цифрового взаимодействия с клиентами - от продажи полиса до урегулирования убытков. Страховые компании оперативно среагировали на меняющиеся условия и стали выводить на рынок полисы страхования от Covid-19, предоставлять клиентам множество цифровых продуктов, а также развивать систему удаленного урегулирования убытков [3].

На современном этапе развития цифровизация страховой отрасли имеет три направления, а именно, интернетизацию, индивидуализацию и диджитализацию. Интернетизация подразумевает осуществление деятельности страховых компаний с использованием сети Интернет (интернет-страхование). Интернет-страхование реализуется посредством интернет-продаж страховых услуг, урегулирования страховых случаев и сбора информации о страхователях через Интернет. Страхование через сеть Интернет имеет положительные и отрицательные стороны как для страховщиков, так и для страхователей (см. табл. 1).

\begin{tabular}{|c|c|c|}
\hline & Страхователь & Страховщикк \\
\hline 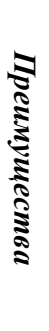 & $\begin{array}{l}\text { - сам выбирает продукт, без «навязанных» вариантов } \\
\text { и дополнительных опций } \\
\text { - сам выбирает место и время оформления полиса } \\
\text { - может выбрать лучший вариант путем сравнения } \\
\text { цен и условий разных страховщиков } \\
\text { - удобно, комфортно, бесконтактно }\end{array}$ & $\begin{array}{l}\text { - экономия на расходах на персонал фронт- и мидл- } \\
\text { офисов } \\
\text { - высокая конверсия в покупку по простым и недоро- } \\
\text { гим страховым продуктам } \\
\text { - экономия в бэк-офисе за счет автоматизации опера- } \\
\text { ционных процессов } \\
\text { - клиенты прямых онлайн-продаж являются самой } \\
\text { качественной и приверженной аудиторией }\end{array}$ \\
\hline 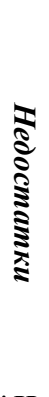 & $\begin{array}{l}\text { - затраты внимания и времени на то, чтобы разобрать- } \\
\text { ся в условиях страхового продукта } \\
\text { - неточность / неполнота информации, неудобный } \\
\text { интерфейс } \\
\text { - существует часть действий, которые необходимо } \\
\text { выполнить оффлайн } \\
\text { - нет возможности получить подсказку / совет } \\
\text { - не все варианты и опции страховых продуктов до- } \\
\text { ступны онлайн }\end{array}$ & $\begin{array}{l}\text { - риски мошенничества и подделки, так как отсут- } \\
\text { ствует визуальная идентификация клиента и докумен- } \\
\text { тов } \\
\text { - риски споров в суде, так как отсутствует живая } \\
\text { подпись клиента } \\
\text { - высокие маркетинговые расходы на привлечение } \\
\text { клиентов } \\
\text { - низкий потенциал по объему продаж (небольшая } \\
\text { доля простых и недорогих продуктов, низкая страхо- } \\
\text { вая культура) }\end{array}$ \\
\hline
\end{tabular}

Можно выделить ряд факторов, которые способствуют развитию интернет-страхования. Во -первых, увеличение количества пользователей Интернета и лиц, осуществляющих операции интернет-коммерции. По данным DigitalIndex, интернет-аудитория России в 2020 г. составила 97 млн человек или 79\% населения страны старше 12 лет [5]. Для сравнения, в 2016 г. в России насчитывалось порядка 84 млн пользователей или 70\% взрослого населения страны.

Во-вторых, появление и совершенствование законодательных норм, регулирующих взаимодействие страховщика и страхователя через Интернет. Примером может служить статья 6.1 Закона РФ об организации страхового дела в Российской Федерации от 27.11.1992 N 4015-1, которая регламентирует особенности обмена информацией в электронной форме между стра- 
хователем и страховщиком.

В-третьих, более высокая рентабельность интернет-продаж страховых услуг и урегулирования страховых случаев через Интернет. Развитию интернет-страхования способствует низкий базовый уровень интернет-продаж на страховом рынке России, о чем свидетельствуют данные табл. 2. Так, доля страховых премий по договорам страхования, заключенным через Интернет, за последние 5 лет не превышала 5\%.

Таблица 2

\begin{tabular}{|c|c|c|c|c|c|}
\hline Показатели & 2016 & 2017 & 2018 & 2019 & 2020 \\
\hline $\begin{array}{l}\text { Премии по договорам страхования, заключенным через } \\
\text { Интернет, млн руб. - всего }\end{array}$ & 5501,7 & 32021,0 & 74651,2 & 67840,8 & 72115,1 \\
\hline Абсолютный прирост, млн руб. & 2330,0 & 26519,3 & 42630,2 & $-6810,4$ & 4274,3 \\
\hline Темп прироста, \% & 73,5 & 482,0 & 133,1 & $-9,1$ & 6,3 \\
\hline \multicolumn{6}{|l|}{ В т. ч.: } \\
\hline по договорам ОСАГО, млн руб. & 2222,4 & 28467,1 & 69233,1 & 58976,0 & 60887,1 \\
\hline по иным договорам, млн руб. & 3279,3 & 3553,9 & 5418,1 & 8864,8 & 11228,0 \\
\hline $\begin{array}{l}\text { Доля страховых премий по договорам ОСАГО в общем количе- } \\
\text { стве премий по договорам, заключенным через Интернет, \% }\end{array}$ & 40,4 & 88,9 & 92,7 & 86,9 & 84,4 \\
\hline Абсолютный прирост, п.п. & 21,1 & 48,5 & 3,8 & $-5,8$ & $-2,5$ \\
\hline $\begin{array}{l}\text { Доля страховых премий по договорам страхования, заключен- } \\
\text { ным через Интернет в общем объеме страховых премий, \% }\end{array}$ & 0,5 & 2,5 & 5,0 & 4,6 & 4,7 \\
\hline 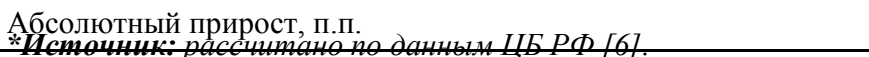 & 0,2 & 2,0 & 2,5 & $-0,4$ & 0,1 \\
\hline
\end{tabular}

Наибольшую долю в общем объеме страховых премий по договорам страхования, заключенным через Интернет, занимают премии по договорам ОСАГО. Это обусловлено тем, что с 1 июля 2015 г. страховщики были вправе оказывать услугу по заключению договора ОСАГО в электронном виде, а с 1 января 2017 г. они стали обязаны предоставлять ее любому автовладельцу [6]. В результате с 2016 по 2018 г. доля премий по ОСАГО увеличилась более чем в 2 раза, с 40,4 до 92,7\%. Однако в последние два года начала сокращаться и в 2020 г. составила $84,4 \%$ от общего количества премий по договорам, заключенным через Интернет. Наглядно

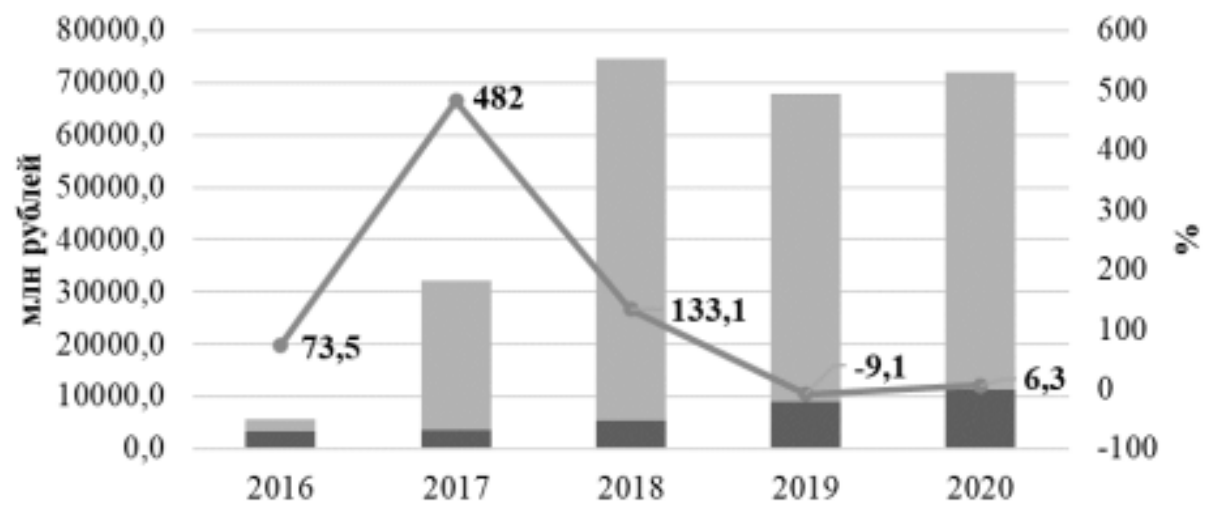

по иным договорам — по договорам ОСАГО —-Темпы прироста премий, \%

Pис. 3. Динамика и структура страховых премий по договорам страхования, заключенным через Интернет

Источник: рассчитано по данным ЦБ РФ [7].

За последние 5 лет объем страховых премий по договорам страхования, заключенным через Интернет, увеличился в 13 раз или на 66,6 млрд руб. Высокие темпы прироста сохраня- 
лись до 2018 г. Однако в 2019 г. премии сократились на 9,1\% (6,8 млрд руб.). Но в 2020 г., увеличившись на 6,3\%, им не удалось достигнуть показателя 2018 г.

Наряду с факторами, стимулирующими интернетизацию страхового рынка, существуют факторы, сдерживающие развитие интернет-страхования. К ним можно отнести высокий уровень страхового мошенничества, потенциальную подверженность операций страхования через Интернет киберпреступлениям, отсутствие полного покрытия территории нашей страны качественным Интернетом, а также невысокий уровень доверия страховым институтам и низкую страховую культуру [8].

Что касается индивидуализации как направления цифровизации страхового рынка, то она включает в себя, с одной стороны, индивидуальную оценку риска за счет увеличения количества информации, собираемой о страхователе и объекте страхования, а с другой - подготовку индивидуального предложения на страхование по запросу страхователя. Таким образом, в условиях цифровой экономики появляется возможность формирования индивидуального предложения без существенного повышения стоимости страхового продукта путем внедрения и использования таких современных технологий, как BigData, технологии Интернет вещей, телематики и др. [9].

Технология BigData дает страховщикам ряд преимуществ. Реализация алгоритмов больших данных повышает эффективность многих процессов, а именно: позволяет быстро проверить историю страхователя, автоматизировать обработку заявок и предоставить клиентам более качественные услуги. BigData поможет компьютеризировать многие ручные процессы, снижая затраты на обработку заявок и администрирование. В условиях конкуренции это приведет к уменьшению стоимости страховки, что привлечет новых клиентов [10].

В последние годы внедрение устройств ІоТ имеет тенденцию к росту, поскольку такие интеллектуальные домашние устройства, как датчики, камеры, термостаты, дверные замки и освещение дают домовладельцам больше возможностей контролировать свой дом со смартфона или с помощью голосовой команды для умного помощника. Технология ІоТ может стать для страховщиков возможностью как простым и эффективным инструментом управления домом для предотвращения или уменьшения распространенных форм ущерба, таких, как вода или пожар. Простое внедрение датчика может дать домовладельцам и арендаторам контекстную информацию об условиях собственности, связанных с водой, огнем, дымом, окисью углерода, открытыми дверями или окнами, влажностью, занятостью помещения, температурой и многим другим. Так, ІоТ может привести к изменению модели страхования для упреждающей защиты домов и имущества. Реализация программы с устройствами может превратить страховщиков в партнеров для домовладельцев в управлении домами и может стать отправной точкой для более надежных интеграций и услуг в будущем [11].

Таким образом, индивидуализация страхового рынка сопровождается рядом проблем, связанных с недостаточной проработкой степени влияния собираемых показателей на риск, с избыточной минимизацией риска вследствие более точной оценки и со снижением размера нетто-ставки существенно ниже уровня расходов страховщика на заключение договора страхования. Появляется угроза приближения к нерисковости договора страхования (приближение к минимально представимому риску, практически не отличимому от нулевого риска). Также существует проблема законности использования собранных данных о страхователе [8].

Третье направление в цифровизации страхования - это диджитализация всех бизнеспроцессов страховщика с помощью использования различных цифровых технологий, а также всех этапов стра-хования, начиная от покупки страхового продукта и заканчивая урегулированием страхового случая. Диджитализация применяется также в таких процессах, как ве-дение бухгалтерского учета, оценка риска и т. д. Во многом степень развития диджитализации будет зависеть от уровня развития блокчейн-технологий, которые неплохо себя зарекомендовали. На сегод-няшний день к основным проблемам диджитализации можно отнести: существующую конкуренцию цифровых каналов с другими каналами услуг страховщиков; безопасность, которая касается и доступа к личным данным; нехватку кадров; сложность применения цифровых технологий из-за необходимости несения огромных затрат на информационное оборудование и обучение специалистов.

Анализ применения цифровых технологий российскими страховыми компаниями 
Перейдем к рассмотрению практического применения российскими страховщиками цифровых технологий. В табл. 3 представлен топ-10 российских страховщиков по электронному страхованию за 2019 г. по версии рейтингового агентства «Эксперт РА». Для объективности рейтинг был составлен агентством без учета страховых премий по договорам ОСАГО.

Абсолютными лидерами данного сегмента являются СПАО «Ингосстрах» и Страховая группа «Альфастрахование»: два года подряд страховщики занимали 1 и 2 позиции в рейтинге соответственно. Объем премий, собираемый данными страховщиками по электронному страхованию, существенно выше показателей компаний, находящихся ниже в рейтинге. В 2019 г. страховые премии СПАО «Ингосстрах» составили 5,46 млрд руб., что на 37,2\% больше показателя предыдущего года. В свою очередь, премии Страховой группы «Альфастрахование» также показали положительную динамику: увеличившись на $8,4 \%$, достигли 3,68 млрд руб. в 2019 г.

СПАО «Ингосстрах» занимает первую строчку рейтинга неслучайно. Еще в 2017 г. компания поняла, что будущее страхования за ИТ-технологиями, и начала активно развиваться в этом направлении. Сейчас на сайте страховщика есть интернет-магазин с 19 страховыми продуктами, которые можно оформить онлайн. Также «Ингосстрах» предоставляет услугу телемедицины, которая позволяет страхователю консультироваться с лечащим врачом онлайн из любой точки мира. Кроме того, «Ингосстрах» предлагает клиентам умное КАСКО с функцией «Телематика». Под телематикой понимается приспособление, которое устанавливается на автомобиле с целью отслеживания поведения водителя на дороге и сбора информации об управлении конкретным автомобилем [12].

В свою очередь, «Альфастрахование» также активно инвестирует в новые технологии и

\begin{tabular}{|c|c|c|c|c|c|c|}
\hline \multicolumn{2}{|c|}{ Место в рейтинге } & \multirow{2}{*}{ Страховщик } & \multicolumn{2}{|c|}{$\begin{array}{c}\text { Страховые премии, } \\
\text { млн руб. }\end{array}$} & \multirow{2}{*}{$\begin{array}{c}\text { Абсолютное } \\
\text { изменение, млн руб. }\end{array}$} & \multirow{2}{*}{$\begin{array}{c}\text { Темп } \\
\text { при-роста, \% }\end{array}$} \\
\hline 2019 & 2018 & & 2019 & 2018 & & \\
\hline 1 & 1 & СПАО «Ингосстрах» & 5461,4 & 3979,3 & 1482,0 & 37,2 \\
\hline 2 & 2 & $\begin{array}{l}\text { Страховая группа } \\
\text { «Альфастрахование» }\end{array}$ & 3684,6 & 3399,4 & 285,2 & 8,4 \\
\hline 3 & 6 & $\begin{array}{l}\text { ООО СК «Сбербанк страхование } \\
\text { жизни» }\end{array}$ & 2686,4 & 630,2 & 2056,2 & 326,3 \\
\hline 4 & 5 & ООО СК «Сбербанк страхование» & 2163,7 & 894,7 & 1269,0 & 141,8 \\
\hline 5 & 3 & Группа Ренессанс Страхование & 815,7 & 919,8 & $-104,1$ & $-11,3$ \\
\hline 6 & 7 & ПАО СК «Росгосстрах» & 632,1 & 481,6 & 150,5 & 31,3 \\
\hline 7 & 9 & ООО «Абсолют Страхование» & 541,7 & 358,1 & 183,6 & 51,3 \\
\hline 8 & 11 & $\begin{array}{l}\text { АО «ЕРВ Туристическое } \\
\text { Страхование» }\end{array}$ & 242,5 & 160,6 & 81,9 & 51,0 \\
\hline 9 & 10 & «Совкомбанк страхование» (АО) & 230,8 & 198,4 & 32,5 & 16,4 \\
\hline $\begin{array}{c}10 \\
* \text { Kcmo } \\
\end{array}$ & $\begin{array}{l}13 \\
\because c o c \\
\because c 0\end{array}$ & $\begin{array}{l}\text { ООО «Страховое общество } \\
\text { «Сургутнедтегаз" иеитингового аг }\end{array}$ & $\begin{array}{r}115,0 \\
8 a \ll Э \kappa c r\end{array}$ & $\begin{array}{c}104,2 \\
m P A »[1]\end{array}$ & 10,8 & 10,4 \\
\hline
\end{tabular}

Следующие две позиции рейтинга в 2019 г. заняли ООО СК «Сбербанк страхование жизни» и ООО СК «Сбербанк страхование». По сравнению с 2018 г. данным страховщикам удалось подняться в рейтинге за счет значительного увеличения размера (в 4,3 и 2,4 раза соответственно) премий по электронному страхованию. Опустившись на 2 позиции и показав отрицательный прирост страховых премий по электронному страхованию, Группа Ренессанс Страхование в 2019 г. заняла 5-е место в рейтинге. Премии страховщика сократились на 11,3\% (104,1 млн руб.) и составили в 2019 г. 815,7 млн руб. Нижнюю половину рейтинга в 2019 г. заняли ПАО СК «Росгосстрах», ООО «Абсолют Страхование», АО «ЕРВ Туристическое Страхование», «Совкомбанк страхование» (АО) и ООО «Страховое общество «Сургутнефтегаз». Эти компании показали высокие темпы прироста страховых премий и поднялись в рейтинге на 1-3 позиции по сравнению с предыдущим годом. 


\begin{tabular}{|l|c|}
\hline \multicolumn{1}{|c|}{ Страховщик } & Доля рынка, \% \\
\hline СПАО «Ингосстрах» & 32,1 \\
\hline Страховая группа «Альфастрахование» & 21,6 \\
\hline ООО СК «Сбербанк страхование жизни» & 15,8 \\
\hline ООО СК «Сбербанк страхование» & 12,7 \\
\hline Группа Ренессанс Страхование & 4,8 \\
\hline ПАО СК «Росгосстрах» & 3,7 \\
\hline ООО «Абсолют Страхование» & 3,2 \\
\hline АО «ЕРВ Туристическое Страхование» & 1,4 \\
\hline «Совкомбанк страхование» (АО) & 1,4 \\
\hline ООО «Страховое общество «Сургутнефтегаз» & 0,7 \\
\hline прочие & 2,7 \\
\hline Всего & 100,0 \\
\hline
\end{tabular}

Следует отметить, что рынок электронного страхования (без учета ОСАГО) в 2019 г. насчитывал лишь 38 из 175 страховщиков (21,7\%) [15]. Это в очередной раз подтверждает, что процесс цифровизации страхового рынка России находится на ранних стадиях. Тем не менее уже сейчас на рынке цифрового страхования существует абсолютный лидер - «Ингосстрах». Его доля составляет почти треть рынка цифрового страхования без учета ОСАГО (табл. 4). «Альфострахованию» принадлежит 21\% данного рынка. Доли «Сбербанк страхование жизни» и «Сбербанк страхование» составляют 16 и 13\% соответственно, а «Ренессанс Страхование» занимает 5\% рынка цифрового страхования. Оставшиеся 13\% составляют прочие страховщики, среди которых «Росгосстрах», «Абсолют Страхование», «Совкомбанк Страхование» и др.

Выводы. Таким образом, можно сделать вывод о том, что в последние 5 лет цифровизация страховой отрасли набирает обороты. Так, в 2020 г. объем страховых премий по договорам, заключенным через Интернет, составил 72,1 млрд руб., что в 13 раз больше показателя 2016 г. Дополнительным импульсом данного процесса стало развитие дистанционного обслуживания клиентов в связи с появлением и распространением коронавирусной инфекции Covid-19.

Основные направления цифровизации (интернетизация, индивидуализация и диджитализация) подразумевают внедрение информационных технологий не только в работу с клиентами, но и во внутренние процессы деятельности страховщиков.

Многие российские страховые компании уже осознали преимущества цифрового страхования. Во-первых, внедрение цифровых страховых решений дает возможность клиентам понимать, что они работают с компанией, использующей новейшие инструменты и технологии с целью предоставить наилучший сервис. Во-вторых, приложения цифрового страхования генерируют огромный объем данных, которые, с одной стороны, помогают страховщикам лучше выполнять свою работу, а с другой - позволяют клиентам получать лучшие условия страхования и сервиса. В-третьих, цифровое страхование увеличивает скорость выхода на рынок новых продуктов, что является возможностью получения дополнительного дохода.

Несмотря на то что цифровизация страховой отрасли в России пока находится на ранних стадиях, компании, внедряющие цифровые приложения и сервисы в свою деятельность, несо-

Литература

1. Любарская, О,. Шкреба, А., Янин, А. Электронное страхование : вынужденное ускорение // Рейтинговое агентство «Эксперт PA». 04.08.2020 [Электронный ресурс]. - URL: https://raexpert.ru/ researches/insurancelets_2019/\#part2 (дата обращения 16.04.2021).

2. Всероссийский союз страховщиков и АC\&M представляют Индекс Цифрового Застрахованного // Всероссийский союз страховщикков. 07.12.2020 [Электронный ресурс]1. - URL : https://ins-union.ru/vss/ 
news/vserossiyskiy-soyuz-strakhovshchikov-i-as-m-predstavlyayut-indeks-tsifrovogo-zastrakhovannogo/ (dama обращчения 16.04.2021).

3. У страха глаза велики - год пандемии страховщики провожают с новыми надеждами // Всероссийский союз страховщиков. 28.12.2020 [Электронный pecypc]. - URL : https://ins-union.ru/press-centre/ press-releases/u-strakha-glaza-veliki-god-pandemii-strakhovshchiki-provozhayut-s-novymi-nadezhdami/ (дата обращения 16.04.2021).

4. InsurSelling-2021. Продажи страхования - стратегия и тактика, трансформаиия и эволюиия, мифы и реальность : материаль конференции // ЗАО Медиа-Информационная Группа "Страхование сегодня» (МИГ). 27 января 2021 [Электронный ресурс]. - URL : https://www.insur-info.ru/InsurSelling/2020/ programm.html (дата обращения 16.04.2021).

5. Романов, А. Индекс циифровой зрелости топ-100 страховых компаний // 3 АО МедиаИнформационная Группа "Страхование сегодня» (МИГ) [Электронный ресурс]. - URL : https:// www.insur-info.ru/InsurSelling/2020/presentations/13_Romanov.pdf (дата обрашения 16.04.2021).

6. Определены требования к обеспечению бесперебойности электронных продаж ОСАГО // Центральный банк Российской Федерации - 11 ноября 2016 г. [Электронный ресурс]. - URL : https://cbr.ru/press/ event/?id=721.

7. Статистические данные к обзору ключевых показателей деятельности страховщиков // Центральный банк Российской Федерации - Информачионно-аналитический материал. - Москва, сор. 2021 [Электронный ресурс]. - URL : https://cbr.ru/insurance/reporting_stat/(daта обращения 16.04.2021).

8. Цыганов, А. А., Брызгалов, Д. В. Цифровизачия страхового рынка : задачи, проблемы и перспективы // Экономика. Налоги. Право. 2018. № 2. - URL : https://cyberleninka.ru/article/n/tsifrovizatsiyastrahovogo-rynka-zadachi-problemy-i-perspektivy (дата обрашения: 18.04.2021).

9. Никулина, Н. Н., Березина, С. В., Шашкина, М. Е. Сущность и технологии индивидуализащии страхования в условиях циифровизаџии // Вестник Московского университета МВД России. 2020. № 3. - URL : https://cyberleninka.ru/article/n/suschnost-i-tehnologii-individualizatsii-strahovaniya-v-usloviyah-tsifrovizatsii (дата обращения: 18.04.2021).

10. Веселовский, Г. Применение Big Data в страховой сфере : с чего начать // HiTech.Expert, Kuев. 10.03.2020 [Электронный ресурс]. - URL : https://www.insur-info.ru/press/153916/ (дата обращения: 18.04.2021).

11. Как ІоТ представляет новые возможности для страхования // Allinsurance.kz, 10.02.2020 2. [Электронный ресурс]. - URL : https://www.insur-info.ru/press/153140/ (дата обращчения: 18.04.2021).

12. Очень умное КАСКО (Телематика) // СПАО «Ингосстрах»: сайт [Электронный ресурс]. - URL : https://www.ingos.ru/auto/kasko/telematics/ (дата обращчения: 18.04.2021).

13. "Альфастрахование» первой среди страховых компаний завериила интеграцию с сервисом «Цифровой профиль» // АO «Альфастрахование», 29.06.2020 2. - URL : https://www.insur-info.ru/ pressr/73752/ (дата обрашения: 18.04.2021).

14. Рэнкинги страховых компаний. Электронное страхование без учета ОСАГО, 2019 // Рейтинговое агентство "Эксперт PA». 2021 [Электронный ресурс]. - URL : https://raexpert.ru/rankingtable/insurance/ ets_2019/tab1/(дата обрашения: 18.04.2021).

15. Реестр страховых организащий // 3АО Медиа-Информаџионная Группа "Страхование сегодня» (МИГ). 2021 [Электронный ресурс]. - URL : https://www.insur-info.ru/register/2019-12/ (дата обращчения: 18.04.2021).

\section{References:}

1. Lyubarskaya, O,. SHkreba, A., YAnin, A. Elektronnoe strahovanie : vynuzhdennoe uskorenie // Rejtingovoe agentstvo "Ekspert RA». 04.08.2020 [Elektronnyj resurs]. - URL : https://raexpert.ru/researches/insurancel ets_2019/\#part2 (data obrashcheniya 16.04.2021).

2. $\bar{V}$ serossijskij soyuz strahovshchikov $i$ AS\&M predstavlyayut Indeks Cifrovogo Zastrahovannogo // Vserossijskij soyuz strahovshchikov. 07.12.2020 [Elektronnyj resurs]1. - URL : https://ins-union.ru/vss/news/ vserossiyskiy-soyuz-strakhovshchikov-i-as-m-predstavlyayut-indeks-tsifrovogo-zastrakhovannogo/) (data obrashcheniya 16.04.2021).

3. U straha glaza veliki - god pandemii strahovshchiki provozhayut s novymi nadezhdami // Vserossijskij soyuz strahovshchikov. 28.12.2020 [Elektronnyj resurs]. - URL : https://ins-union.ru/press-centre/press-releases/ustrakha-glaza-veliki-god-pandemii-strakhovshchiki-provozhayut-s-novymi-nadezhdami) (data obrashcheniya 16.04.2021).

4. InsurSelling-2021. Prodazhi strahovaniya - strategiya $i$ taktika, transformaciya $i$ evolyuciya, mify $i$ real'nost' : materialy konferencii // ZAO Media-Informacionnaya Gruppa «Strahovanie segodnya» (MIG). 27 yanvarya 2021 [Elektronnyj resurs]. - URL : https://www.insur-info.ru/InsurSelling/2020/programm.html (data obrashcheniya 16.04.2021).

5. Romanov, A. Indeks cifrovoj zrelosti top-100 strahovyh kompanij // ZAO Media-Informacionnaya Gruppa «Strahovanie segodnya» (MIG) [Elektronnyj resurs]. - URL : https://www.insur-info.ru/InsurSelling/2020/ presentations/13 Romanov.pdf (data obrashcheniya 16.04.2021).

6. Opredeleny trebovaniya $k$ obespecheniyu besperebojnosti elektronnyh prodazh OSAGO // Central'nyj bank Rossijskoj Federacii - 11 noyabrya 2016 g. [Elektronnyj resurs]. - URL: https://cbr.ru/press/event/?id=721.

7. Statisticheskie dannye $k$ obzoru klyuchevyh pokazatelej deyatel'nosti strahovshchikov // Central'nyj bank Rossijskoj Federacii - Informacionno-analiticheskij material. - Moskva, cop. 2021 [Elektronnyj resurs]. URL: https://cbr.ru/insurance/reporting_stat/(data obrashcheniya 16.04.2021).

8. Cyganov, A. A., Bryzgalov, D. V. Cifrovizaciya strahovogo rynka : zadachi, problemy $i$ perspektivy // Ekonomika. Nalogi. Pravo. 2018. № 2. - URL : https://cyberleninka.ru/article/n/tsifrovizatsiya-strahovogo- 
rynka-zadachi-problemy-i-perspektivy (data obrashcheniya: 18.04.2021).

9. Nikulina, N. N., Berezina, S. V., SHashkina, M. E. Sushchnost' i tekhnologii individualizacii strahovaniya v usloviyah cifrovizacii // Vestnik Moskovskogo universiteta MVD Rossii. 2020. № 3. - URL : https:// cyberleninka.ru/article/n/suschnost-i-tehnologii-individualizatsii-strahovaniya-v-usloviyah-tsifrovizatsii (data obrashcheniya: 18.04.2021).

10. Veselovskij, G. Primenenie Big Data v strahovoj sfere : s chego nachat' // HiTech.Expert, Kiev. 10.03.2020 [Elektronnyj resurs]. - URL : https://www.insur-info.ru/press/153916/(data obrashcheniya: 18.04.2021).

11. Kak IoT predstavlyaet novye vozmozhnosti dlya strahovaniya // Allinsurance.kz, $10.02 .2020 \mathrm{~g}$. [Elektronnyj resurs]. - URL : https://www.insur-info.ru/press/153140/(data obrashcheniya: 18.04.2021).

12. Ochen' umnoe KASKO (Telematika) // SPAO «Ingosstrah»: sajt [Elektronnyj resurs]. - URL : https:// www.ingos.ru/auto/kasko/telematics/ (data obrashcheniya: 18.04.2021).

13. "Al'fastrahovanie» pervoj sredi strahovyh kompanij zavershila integraciyu s servisom «Cifrovoj profil'» // AO "Al'fastrahovanie», 29.06.2020 g. - URL : https://www.insur-info.ru/pressr/73752/ (data obrashcheniya: 18.04.2021).

14. Renkingi strahovyh kompanij. Elektronnoe strahovanie bez ucheta OSAGO, 2019 // Rejtingovoe agentstvo «Ekspert RA». 2021 [Elektronnyj resurs]. - URL : https://raexpert.ru/rankingtable/insurance/ets_2019/tab1/ (data obrashcheniya: 18.04.2021).

15. Reestr strahovyh organizacij // ZAO Media-Informacionnaya Gruppa «Strahovanie segodnya»(MIG). 2021 [Elektronnyj resurs]. - URL : https://www.insur-info.ru/register/2019-12/ (data obrashcheniya: 18.04.2021). 